\title{
Corporate governance in the European context
}
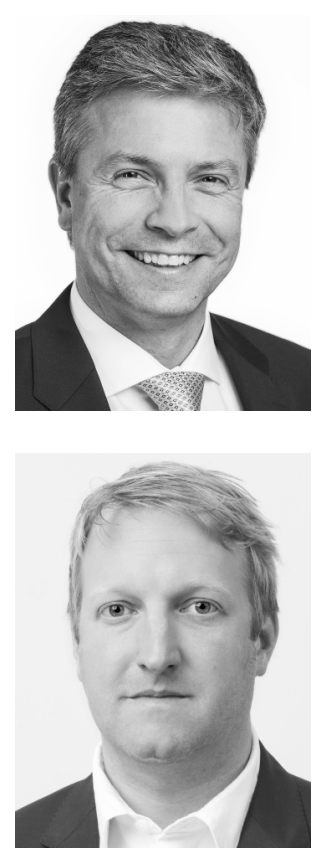

\section{Pascal Gantenbein \& Christophe Volonté}

The purpose of corporate governance is to ensure that the owners of companies are protected against value-decreasing activities by corporate insiders. The way this protection is pursued, however, varies among countries and legal systems. While most research so far has focused on Anglo-Saxon countries, little is known about the specific differences and drivers of corporate governance structures in countries belonging to the Civil Law legal system. We examine the differences in corporate governance of blue-chip companies in Austria, France, Germany, Italy, and Switzerland, and analyze the influence of the institutional framework and the operating environment on corporate ownership and board structures. Despite convergence trends and the fact that all included countries apply the Civil Law legal system, we find that corporate governance structures differ in many aspects and depend both on the institutional framework and the operating environment. The institutional framework is important to explain the distribution of ownership and the independence of the board of directors, while the operating environment explains the size of the board and differences in ownership between the financial services industry and the consumer goods industry.

Corporate Governance-Mechanismen haben den Schutz der Unternehmenseigner vor wertmindernden Handlungen seitens des Managements und dominanter Aktionäre zum Ziel. Die Ausgestaltung dieser Vorkehrungen ist indessen je nach Land und Rechtssystem unterschiedlich. Während die bisherige Forschung sich hauptsächlich auf angelsächsische Länder fokussiert hat, ist wenig bekannt über Corporate Governance-Mechanismen in Ländern, welche nach dem römisch-germanischen Rechtskreis organisiert sind. Im vorliegenden Beitrag untersuchen wir den Einfluss des institutionellen Rahmens sowie des Geschäftsumfelds auf die Ausgestaltung der Corporate Governance von Blue-Chip-Unternehmen in Österreich, Frankreich, Deutschland, Italien und der Schweiz. Betreffend Corporate Governance-Aspekten stehen die Eigentumsverhältnisse sowie die Zusammensetzung des Verwaltungsrats im Zentrum. Trotz einer Konvergenz der Strukturen und der Tatsache, dass alle untersuchten Länder dem römisch-germanischen Rechtskreis angehören, zeigen sich Unterschiede in den Corporate Governance Strukturen, die auf die institutionellen und unternehmensspezifischen Rabmenbedingungen zurückzuführen sind. Der institutionelle Rabmen eines Landes hat dabei einen Einfluss auf die Unabhängigkeit des Verwaltungsrats sowie auf die Eigentumsverhältnisse. Dagegen stehen die Grösse des Gremiums sowie die Beobachtung eines breiter gestreuten Aktionariats bei Unternehmen des Finanzbereichs (im Gegensatz etwa zu solchen der Konsumgüterindustrie) im Zusammenhang mit branchenspezifischen Charakteristika.

corporate governance, board of directors, ownership, independence, institutional framework, legal system 
Corporate Governance, Verwaltungsrat, Aufsichtsrat, Eigentum, Unabhängigkeit, institutioneller Rahmen, Rechtssystem

\section{Introduction}

Companies in the legal form of a public limited company play a crucial role in the economy of many countries ${ }^{1}$. This type of company had its origin in trade financing. For instance, large sea voyages were generally too expensive and too risky to be financed by a single investor. The way forward therefore was to set up a suitable structure to bundle resources from a large number of investors in order to carry out larger undertakings. At the same time, the risk was associated with the prospect of a return.

The first public limited company, Verenigde Oostindische Compagnie (VOC), was founded in Amsterdam in $1602^{2}$. The VOC (until 1782) obtained the monopoly from the Dutch state for trade, especially with spices from Indonesia, and it had 70 board members ("bewindhebbers") (Gelderblom/De Jong/Jonker 2013). The VOC already featured the key elements of a modern joint-stock company: legal identity, separation of ownership and control, co-ownership and profit-sharing of shareholders, limited liability of shareholders, and tradability of shares on a stock exchange. Investors were able to diversify their investments and minimize their risk, while this setting enabled the contractors to specialize in their work. Railway construction and industrialization would not have been possible without modern joint-stock companies of this kind. With the industrial revolution, this form of organization spread across industries and countries.

However, the described advantage of scalability also means that decision-making rights must be delegated to a smaller body. In contrast to a sole proprietorship, in public limited companies, managing directors (manager) and financiers (shareholders) are typically not identical. This can cause problems. Already Adam Smith (1776) pointed out a possible conflict of interest between managers and shareholders. Later, Berle and Means (1932) in their seminal work in this field, described the problems arising from the separation of ownership and control in large public limited companies that evolved in the 19th century. Nevertheless, the economic boom in the post-war period of the $20^{\text {th }}$ century and the takeover waves over the past four decades have driven the emergence of ever larger and more complex companies.

Such structures need an appropriate corporate governance. The principal-agent theory developed by Jensen and Meckling (1976) still provides the basis of modern corporate governance: Its elements are designed to prevent self-interested agents (managers) from making decisions that increase their personal benefit at the cost of principals (shareholders). Corporate governance should ensure that shareholders receive an appropriate return on their investments ${ }^{3}$ and that decisions and operations within corporations are conducted professionally. Management and control failures instead can lead to business and econo-

1 Cf. Allen, Kraakman and Subramanian (2009)

2 See Hopt and Leyens (2004). Forerunners were, for example, the trading companies Muscovy Company (founded in 1566 and liquidated in 1917) or Levant Company (1581 to 1825) as well as the British East India Company (1600 to 1858) which was decisively (above all warlikely) involved in the construction of the British Empire.

3 Cf. Shleifer and Vishny 1997. There are many different definitions of corporate governance, but in the end, all of them describe corporate governance in such a way that it should enable the long-term creation of corporate values, also taking into account possible stakeholder interests or the concept of Corporate Social Responsibility. 
mic crises. The problems of, e.g., Enron, Parmalat, Swissair as well as the economic crisis in Asia (1997) or the financial crisis of 2008 were attributed, among other things, to failures of corporate governance structures ${ }^{4}$. Essential elements of corporate governance include shareholder democracy (i.e., the distribution of power and the right of the various shareholder groups to have a say at the Annual General Meeting), the board of directors, and the creation of incentives by means of suitable compensation systems ${ }^{5}$.

The academic discourse on corporate governance has long been shaped by U.S. reality and has become increasingly relevant in other parts of the world in the wake of the corporate scandals in Europe and Asia. However, it is difficult to apply the same corporate governance "recipes" to all companies globally. It is a widely shared view in research that the effectiveness of corporate governance depends on the company's environment and that not always the same features of corporate governance may be suitable. Therefore, "one size fits all" approaches may not be appropriate ${ }^{6}$ for governance mechanisms and regulation in this area.

The company's environment with regard to corporate governance (e.g., the composition of the board of directors) is shaped, in particular, by the institutional framework ${ }^{7}$, the operational environment ${ }^{8}$, and the ownership structure (i.e., the shareholders themselves) ${ }^{9}$. As an example, the optimal corporate governance structure of a family-led textile company in Asia is likely to be different from the one of a U.S. based pharmaceutical company with dispersed and rather passive institutional shareholders.

Against this background, the aim of this study is to identify differences in corporate governance among five Western European countries that are geographically close. Law and finance theory as postulated by La Porta, Lopez-de-Silanes, Shleifer, and Vishny (1998) attributes international differences in corporate governance to legal origins and draws a distinction between Anglo-Saxon common law on the one hand and Continental European civil law on the other. More recent studies have investigated the influence of the institutional environment together with firm-specific factors on corporate governance. Doidge, Karolyi, and Stulz (2007) document that country variables are more important than firm variables for explaining firm corporate governance. Klapper, Laeven, and Love (2006) in contrast see both areas as similarly important. However, this also depends on the strength of the institutions in the respective countries ${ }^{10}$. Griffin, Guedhami, Kwok, Li, and Shao (2017) measure the influence of culture on corporate governance ratings. They find that individualism on a country level is positively associated with corporate governance scores, while uncertainty avoidance is negatively associated with it. Furthermore, La Porta, Lopez-de-Silanes, and Shleifer (1999) document that control structures vary significantly across countries. And Boone, Field, Karpoff, and Raheja (2007) as well as Lehn, Patro, and Zhao (2009) show that board composition and board size are determined by a firm's operating environment such as firm size.

In this study, we investigate whether a firm's environment has an impact on its corporate governance. We therefore examine to what extent the institutional framework has an influence on corporate governance within the legal sphere of civil law. Country affiliation

4 Cf. Johnson, Boone, Breach and Friedman (2000); DeYoung, Peng and Yan (2013)

5 Cf. Shleifer and Vishny (1997); Denis and McConnell (2003)

6 Cf. Hermalin and Weisbach (2003)

7 Cf. La Porta, Lopez-de-Silanes, Shleifer and Vishny (1998); Klapper and Love (2004)

8 Cf. Coles, Daniel and Naveen (2008); Linck, Netter and Yang (2008); Lehn, Patro and Zhao (2009)

9 Cf. Shleifer and Vishny (1997); Villalonga and Amit (2006)

10 Cf. Klapper and Love (2004) 
captures differences in legislation and law enforcement in the respective countries as well as the historical and cultural circumstances that led to the structures observed today. In addition to country affiliation, we examine whether the operating environment of the largest listed and comparable companies surveyed are important determinants of corporate governance. Rather than examining broad corporate governance ratings as a proxy for corporate governance mechanisms such as in Doidge, Karolyi, and Stulz (2007) or Griffin, Guedhami, Kwok, Li, and Shao (2017), the particular focus of this study is on the extent to which two key elements of corporate governance, namely the ownership structure and the board of directors, are influenced by the companies' environment. Specifically, we examine the most common factors and distinguish between widely-held companies and the ones dominated by a family. We also analyze the size and independence of the board of directors ${ }^{11}$. The empirical analysis is based on a sample of blue-chip companies in five Continental European countries which are likely to be similar in their characteristics and therefore provide a good basis for comparisons.

Adding to previous literature, this study expands research in three dimensions: First, it examines, how differences in corporate governance can be explained within the theoretical concept and whether the differences also hold empirically. Second, we contribute to the discussion about the convergence vs. divergence theories on corporate governance as postulated by Coffee (1999) and Bebchuk and Roe (1999), respectively. We therefore also provide some historical background on the examined countries' corporate governance. Thirdly, in line with Pargendler's (2019) findings on economic nationalism's role on the evolution of corporate law, we provide evidence that politics play an important role in today's corporate governance. Hence, in contrast to existing corporate governance literature, we apply a broader perspective on the setting and development of corporate governance in these Continental European countries.

\section{Theoretical background}

At the core of the corporate governance debate, the question is how shareholders can be protected against value-decreasing activities by company insiders such as managers or major shareholders, and how the company can be driven towards creating long-term value. Value-decreasing activities could, for instance, include investments in favorite projects of business leaders (so-called pet projects) ${ }^{12}$ or remuneration policies creating false incentives or paying disproportionate remunerations ${ }^{13}$. The agency problem arises, if managers make and drive decisions that are not in the full interest of the shareholders. Due to the asymmetric distribution of information between managers and shareholders and due to the free-rider problem, shareholders lack the opportunities or incentives to prevent this. This case setting is a major focus of American corporate governance theory. Corporate governance mechanisms should therefore contribute to mitigating the principal-agent problem. In most countries, however, a second problem is more relevant, namely the risk that large shareholders (e.g., families) influence decisions that are not in the interest of the minority shareholders ${ }^{14}$.

11 Cf. La Porta, Lopez de Silanes and Shleifer (1999); Faccio and Lang (2002)

12 Cf. Shleifer and Vishny (1997)

13 Cf. Gillan (2006)

14 Cf. Shleifer and Vishny (1997); La Porta, Lopez-de-Silanes, Shleifer and (2000) 
The design of corporate governance also depends on the view about which goals are to be pursued by the entrepreneurial activity. While corporate decisions according to the shareholder value concept as defined by Friedman (1970) are aimed at maximizing corporate value, stakeholder orientation takes into account the interests of a wider range of stakeholders such as employees, customers, and the state ${ }^{15}$. This view of economic activity is relatively widespread in Continental Europe and is increasingly relevant in the AngloSaxon practice. The term "corporate social responsibility" includes aspects of environmental, social, and governance (ESG) issues which are increasingly seen as investment criteria for investors ${ }^{16}$.

The business goal of each company is therefore influenced by different values. In addition, legal and economic systems of different countries are shaped by historical, political, and cultural circumstances, which is why different "varieties of capitalism" have prevailed" 17

\subsection{Types of shareholder protection}

With regard to shareholder protection, three dimensions can be distinguished:

First, the (1) State offers legal protection for shareholders. In countries with a functioning legal system, minimum legal standards (e.g., fiduciary duties and due diligence) protect shareholders from unlawful conduct by management. Managers can be prosecuted for embezzlement of assets or property ${ }^{18}$. In addition, the quality of the legal system influences the nature of contract negotiations between managers and shareholders, for example with regard to control rights in the case of start-up companies ${ }^{19}$.

In addition, (2) social pressure as extra-legal shareholder protection can ensure that norms and values are observed as "informal rules" ${ }^{20}$. For example, managers must expect considerable damage to their reputation if the media or politicians discover misconduct ${ }^{21}$. It is therefore often difficult for managers who have fallen out of public favor to regain a foothold in business. The form of this extra-legal shareholder protection depends on the cultural values and norms of a company and society. Shareholder protection of these two elements is therefore characterized by formal and informal institutions ${ }^{22}$.

Finally, (3) corporate governance provides shareholder protection at the corporate level. It can be codified, for example, in the Articles of Association or Organizational Regulations and thereby influences the rights and duties as well as the behavior of management within the company. Hence, this investor protection (voluntarily) reaches beyond statutory minimum standards. However, the scope of this self-regulation is determined by the legislator.

15 Cf. Rappaport (1986) or Freeman (1984)

16 Pagano and Volpin 2001; Doh and Guay (2006). In this context, it is also worthwhile noting the occasional return to cooperatives with characteristics that seem to describe "social economies". 2012, for example, was the "UN year of cooperatives". And cooperative companies often advertise offensively with the cooperative idea. Unlike shareholders, cooperative members have no right to receive a profit, and each member has one vote, regardless of his or her share. Membership is often free of charge. Since a profit distribution is not planned, there is a risk of overinvestment or "empire building" as known from agency theory. Since cooperative shares are not freely traded, a takeover is practically impossible.

17 Hall and Soskice (2001); Morck and Yeung (2005); Frank, Mayer and Rossi (2005)

18 Cf. Shleifer and Vishny (1997)

19 Cf. Kaplan and Strömberg (2003)

20 Cf. North (1990)

21 Cf. Dyck and Zingales (2004)

22 Cf. Dyck and Zingales (2004) 


\subsection{Corporate governance mechanisms and the legal system}

The principles of corporate governance are based on incentives, control, and competition. An incentive-oriented compensation policy is designed to harmonize the interests of managers with those of shareholders. For example, a manager who is also compensated with company shares potentially has a higher interest to increase the value of the company than a manager who receives a fixed cash compensation only ${ }^{23}$. In addition, various control bodies (e.g., the board of directors, shareholders, and creditors) monitor the management. As delegates of shareholders, the board of directors has a direct incentive to control the management ${ }^{24}$. Moreover, competition forces companies to use their resources efficiently. Especially in the Anglo-Saxon market, management teams can be exposed to a market for corporate control: A management not providing the desired services runs the risk of being replaced by other managers in a hostile takeover ${ }^{25}$. Also, the labor market forces managers to act in the interests of the company. Otherwise, there is the possibility of dismissal. Similarly, competition on the product market ensures that companies use their resources to add value. Transparency is a prerequisite for these mechanisms to be effective.

These mechanisms are strongly dependent on the legal system of the country from which the respective company is running its operations. The design of the legal system is an important determinant of the development of financial markets, ownership structures, corporate governance mechanisms, and economic development in general26. Legal systems can broadly be segmented into common law and civil law, the latter being further differentiated according to German, French or Scandinavian coinage ${ }^{27}$. It is sometimes argued that common law (particularly in comparison to French civil law) is more conducive to economic development.

With regard to the interaction between the economic system and legislation, law and finance theory shows that due to the higher protection of minority investors in countries with common law, the ownership structure is more dispersed than in countries with civil law. This means that in Anglo-Saxon countries, a larger proportion of companies are held by many small shareholders, as opposed to European or Asian companies, which are often

23 Cf. Mehran (1995)

24 Cf. Fama and Jensen (1983)

25 Cf. Jensen and Ruback (1983)

26 Cf. La Porta, Lopez-de-Silanes, Shleifer and Vishny (1998); Beck, Demirgüç-Kunt and Levine (2003); La Porta, Lopez-de- Silanes and Shleifer (2008).

27 The common law is based on precedents and judiciary law and is therefore referred to as case law, formed by the jurisdiction of the courts. In contrast, civil law has its roots in Roman law and consists of specific codes of law. It is therefore largely determined by the legislature. The first uniformly written law in France was the Code Civil from 1804, which was introduced by Napoleon (therefore also temporarily called Code Napoléon) and which was influenced by the French Revolution and spread in Europe. Almost 100 years later, the German Civil Code, which is characterized by a systemization, was introduced in Germany. English common law, like French civil law, has spread in the conquered and colonized territories. Due to the importance of French law in Spain and Portugal, the sphere of influence of civil law has extended to South America: This also applies, in parts, to Louisiana (U.S.A.) and Québec (Canada). German, Swiss, and Austrian law developed at a similar time. This was also adopted in Eastern Europe (e.g., Czech Republic or Hungary) as well as in Japan or China (Beck/ Levine 2005). However, Swiss law is less based on Roman law than German law (Berkowitz/Pistor/ Richard 2003): In the wake of the Founder Crisis (Gründerkrise) in 1873, German investor protection tended towards more detailed rules, while in Switzerland, more emphasis was placed on self-regulation. In the United States, fear of overpowering managers and Wall Street actors was a reason for orientation towards minority investor protection (Roe 1991). 
controlled by families ${ }^{28}$. One explanation for this is that there are incentives for shareholders to increase their ownership stake in environments with less pronounced minority investor protection, as they can derive private benefits from control ${ }^{29}$. Specifically, shareholders can pursue different interests and have no legal obligations whatsoever to act in the interest of the company, in contrast to the board of directors.

The different forms can therefore be well illustrated by the ownership structure of companies. The typical listed U.S. company, for example, has a relatively broad shareholder base. Dissatisfied shareholders "vote with their feet" ("wall street walk") ${ }^{30}$ and commonly sell their shares instead of actively exercising their voting rights. The emergence of private provisions in the United States, however, has also turned institutional investors into key players of shaping corporate governance. Activist investors such as pension funds (e.g., Calpers), hedge funds (e.g., Ican Cahn) or, in recent years, proxy advisors (e.g., ISS) often exert considerable pressure on management. In addition, price pressure on the stock markets and the risk of an unfriendly takeover have a disciplining effect, as well. Hence, the ownership structure is the most important characteristic of a firm's corporate governance as the owners can exercise influence by means of their voting rights.

The most fundamental features of governance are defined by the firm's owners in the articles of association. The owners also elect delegates on the board of directors whose main purpose should be to direct the company towards creating long-term value ${ }^{31}$. The composition of the board of directors is therefore crucial and large shareholders, activist investors, or new shareholder groups typically aim to replace directors who they believe are not protecting their interests ${ }^{32}$. For these reasons, the structure of ownership and the board of directors are generally seen as the most important elements of corporate governance.

To illustrate the countries' influence on ownership and board structures, let's look at business groups. In some countries, large corporate groups, interlocking companies, or companies controlled by families play a significant role. These corporations are largely protected from hostile shareholder activities. In Germany, for example, a network of house banks and companies, the so-called "Deutschland AG", for many years ensured that several companies were linked to each other. In Japan, highly diversified corporate groups, often led by banks, are loosely grouped into so-called "keiretsus" through crossshareholdings of various companies. Examples include Mitsubishi, Sumitomo, Yasuda or Mitsui, which are players in numerous industries such as financial services, construction, automotive engineering, food production, paper production, freight or oil production ${ }^{33}$. Another link is family control as can be seen in Korea with the "chaebols", similar to the "zaibatsu" in Japan ${ }^{34}$. Another feature is the close interdependence between such conglomerates and politics. In these contexts, the board of directors often consists of a number of handpicked men.

28 Cf. La Porta, Lopez-de-Silanes, Shleifer and Vishny (1998); La Porta, Lopez-de-Silanes and Shleifer (1999); Claessens, Djankov and Lang (2000)

29 Cf. Dyck and Zingales (2004)

30 Cf. Admati and Pfleiderer (2009)

31 Cf. La Porta, Lopez-de-Silanes, and Shleifer (1999)

32 Cf. Adams, Hermalin, and Weisbach (2010)

33 Cf. Hattori (1989)

34 Cf. Shin and Park (1999), Ferris, Kim and Kitsabunnarat (2003) 


\subsection{Institutional framework, operational environment, and ownership structure}

As the previous sections have shown, three areas of a company's environment are supposed to have an important influence on the effectiveness of corporate governance: namely the institutional framework, the operational environment, and the ownership structure.

The (1) institutional framework can generally be considered as country-specific. The legal environment (e.g., stock corporation law, stock exchange regulations, or industry-specific regulations) and the cultural environment vary from country to country, resulting in different corporate governance requirements. Furthermore, the (2) operational environment, which can be captured, e.g., by industry affiliation, size, and corporate strategy (e.g., diversification, internationalization), defines which corporate governance is most conducive to the corporate goals. Smaller, fast-growing companies, for example, need a corporate governance design that differs from the one in large, diversified and established companies. Finally, the (3) ownership structure has a considerable influence on shareholder democracy. The rights granted to the various shareholder groups depend on the balance of power within the anchor shareholders and thus have a major influence on the structure of corporate governance. Shareholder rights and the composition of the board of directors are usually established by shareholders' votes at General Meetings.

Since the relationship between corporate governance and corporate performance is very complex and dependent on various factors, we make no explicit statement on the effectiveness of the various corporate governance structures. Companies face different challenges in different institutional environments, different operating environments and different ownership structures. This makes it difficult to conduct a transnational study on the effectiveness of corporate governance. We therefore confine ourselves to examining differences in corporate governance that can be attributed to country affiliation and the operating environment. Based on this perspective, we derive the following hypotheses for our investigation:

Hypothesis 1: The country affiliation has an impact on the typical setting of corporate governance, irrespective of the industry affiliation of the firm.

Hypothesis 2: Operating characteristics of firms active in specific industries have an impact on the design of corporate governance mechanisms.

\section{Country-specific differences in corporate governance}

The legal environment is often used to explain ownership structures, such as the rather dispersed structure in the United States, for example. Alternative explanations for dispersed ownership include the regulation of the stock exchanges ${ }^{35}$, the original ownership structure in the country, and the pressure of interest groups according to the path dependency theory ${ }^{36}$, the skepticism towards a concentration of power at Wall Street ${ }^{37}$, the development of the stock corporation law of $1930^{38}$, as well as the influence of various economic actors and takeover waves ${ }^{39}$. Corporate governance structures observed today

35 Cf. Coffee (2001)

36 Cf. Bebchuk and Roe (1999)

37 Cf. Roe (1991)

38 Cf. Gillan and Starks (2007)

39 Cf. Aguilera and Jackson (2003) 
therefore may be driven by various determinants including the legal, the historical, and the cultural environment.

In Table 1, the legal systems and their characteristics as well as individual elements of corporate governance are presented within a framework of country comparison. We survey main corporate governance characteristics of five Western European countries that are geographically close: Austria, France, Germany, Italy, and Switzerland.

Table 1: Overview Corporate Governance

\begin{tabular}{|c|c|c|c|c|c|}
\hline Legal system & $\begin{array}{l}\text { Austria } \\
\text { German legal } \\
\text { system } \\
\text { German civil law }\end{array}$ & $\begin{array}{l}\text { France } \\
\text { Roman legal } \\
\text { system } \\
\text { French civil law }\end{array}$ & $\begin{array}{l}\text { Germany } \\
\text { German legal } \\
\text { system } \\
\text { German civil law }\end{array}$ & $\begin{array}{l}\text { Italy } \\
\text { Roman legal } \\
\text { system } \\
\text { French civil law }\end{array}$ & $\begin{array}{l}\text { Switzerland } \\
\text { German legal } \\
\text { system } \\
\text { German civil law }\end{array}$ \\
\hline $\begin{array}{l}\text { Strength of law }{ }^{1} \\
(0-10)\end{array}$ & 7.00 & 7.00 & 7.00 & 3.00 & 8.00 \\
\hline $\begin{array}{l}\text { Principle of the } \\
\text { rule of } \text { law }^{2}(0-10)\end{array}$ & 10.00 & 8.98 & 9.23 & 8.33 & 10.00 \\
\hline $\begin{array}{l}\text { Efficiency of the le- } \\
\text { gal system }{ }^{2}(0-10)\end{array}$ & 9.50 & 8.00 & 9.00 & 6.75 & 10.00 \\
\hline $\begin{array}{l}\text { Protection of mi- } \\
\text { nority sharehold- } \\
\text { ers }^{3}(0-1)\end{array}$ & 0.21 & 0.38 & 0.28 & 0.39 & 0.27 \\
\hline $\begin{array}{l}\text { Corporate Gover- } \\
\text { nance Code }\end{array}$ & $\begin{array}{l}\text { Österreichischer } \\
\text { Corporate Gov- } \\
\text { ernance Kodex } \\
\text { Editor: } \\
\text { Österreichischer } \\
\text { Arbeitskreis für } \\
\text { C.G. } \\
\text { Year: } 2002\end{array}$ & $\begin{array}{l}\text { Code de } \\
\text { gouvernement } \\
\text { d'entreprise des } \\
\text { sociétés cotées } \\
\text { Editor: } \\
\text { AFEP-MEDEF } \\
\text { Year: } 1995 \\
\text { (Viénot Report) }\end{array}$ & $\begin{array}{l}\text { Deutscher Cor- } \\
\text { porate Gover- } \\
\text { nance Kodex } \\
\text { Editor: } \\
\text { Regierungskom- } \\
\text { mission } \\
\text { Year: } 2002\end{array}$ & $\begin{array}{l}\text { Codice di Au- } \\
\text { todisciplina } \\
\text { Editor: } \\
\text { Borsa Italia } \\
\text { S.p.A } \\
\text { Year: } 1999\end{array}$ & $\begin{array}{l}\text { Swiss Code of } \\
\text { Best Practice } \\
\text { Editor: } \\
\text { Economiesuisse } \\
\text { Year: } 2002\end{array}$ \\
\hline $\begin{array}{l}\text { Example of corpo- } \\
\text { rate scandal }\end{array}$ & Bawag (2006) & Vivendi (2002) & Flowtex (1999) & $\begin{array}{l}\text { Parmalat } \\
(2003)\end{array}$ & Swissair (2001) \\
\hline Board system & Two-tier & One-tier & Two-tier & One-tier & One-tier \\
\hline Description & $\begin{array}{l}\text { Aufsichtsrat/ } \\
\text { Vorstand }\end{array}$ & $\begin{array}{l}\text { Traditional: } \\
\text { PDG-System } \\
\text { Monistic: } \\
\text { conseil d'ad- } \\
\text { ministration } \\
\text { Dualistic: } \\
\text { conseil de } \\
\text { surveillance/ } \\
\text { directoire }\end{array}$ & $\begin{array}{l}\text { Aufsichtsrat/ } \\
\text { Vorstand }\end{array}$ & $\begin{array}{l}\text { Traditional: } \\
\text { Consiglio di } \\
\text { amminis- } \\
\text { trazione/ colle- } \\
\text { gio sindacale } \\
\text { (Prüferkol- } \\
\text { legium) } \\
\text { Monistic: } \\
\text { Consiglio di } \\
\text { amminis- } \\
\text { trazione inkl. } \\
\text { Comitato di } \\
\text { controllo. } \\
\text { Dualistic: } \\
\text { Consiglio di } \\
\text { sorveglianza/ } \\
\text { Consiglio di } \\
\text { gestione }\end{array}$ & Verwaltungsrat \\
\hline
\end{tabular}

${ }^{1}$ World Bank Group 2014: "Strength of legal rights index"

${ }^{2}$ La Porta, Lopez-de-Silanes, Shleifer und Vishny (1998): "Rule of law" und "Efficiency of judicial system"

${ }^{3}$ Djankov, La Porta, Lopez-de-Silanes and Shleifer (2008): Anti-Self-Dealing Index 
Table 1 shows that based on three key indicators of a legal system (strength of law, rule of law, and enforcement), German civil law performs better than French civil law. However, as far as minority investor protection is concerned, as measured by the Anti-Self-Dealing Index ${ }^{40}$, French civil law depicts a higher value than German civil law. It should be noted, though, that this protection is considerably lower than in Anglo-Saxon countries (Great Britain: 0.93; United States: 0.65; Australia: 0.79; Canada: 0.65; New Zealand: 0.95). Conac, Enriques and Gelter (2007) emphasize, however, that France as well as Germany and Italy employ different legal strategies to prevent self-dealing and that these cannot be reflected in an index.

Another important pillar in almost all countries are corporate governance codes which provide guidelines and principles of "Best Practice" for mostly listed companies. They describe the idea of "good" corporate governance in a country and thus give insights into stakeholders' expectations. Already in 1992, the "Cadbury Report" was published in Great Britain. In the course of corporate scandals (e.g., Enron, Worldcom) around the turn of the millennium, such codes were subsequently created in many other countries too. Although the core of these standards is similar throughout various countries, they are generally self-regulatory in nature and allow for sufficient entrepreneurial space. Accordingly, it can be assumed that despite the convergence trends in corporate governance guidelines, country-specific peculiarities have been preserved.

The European Union public limited company also offers the possibility of registering with the legal form of a Societas Europaea ("S.E.") with uniform legal principles throughout Europe. In Germany and Austria, for example, the two-tier board model is mandatory, while in France, Italy and Switzerland, companies can opt for one-tier or two-tier board systems. With the S.E., it would also be possible to introduce a monistic board system in Germany, although national law applies for further regulation and for implementation.

\subsection{Short Corporate Governance Overview on the Five Countries}

Despite certain similarities between the legal systems (especially in contrast to common law), there have been many country-specific developments with regard to corporate governance in recent years. Although such regulations apply only in the respective jurisdictions (e.g., for women's quotas), companies in other countries may consider such adjustments on a voluntary basis or as a result of political or media pressure. At the same time, there are efforts to standardize corporate governance throughout Europe, e.g., by strengthening shareholder democracy ${ }^{41}$.

Austria: Austria's corporate governance system can be compared to that of Germany. With a focus on the stakeholder approach, the executive board is separated from the supervisory board. In addition, employees are represented on the supervisory board. Austria has also experienced a wave of privatization since the fall of the Iron Curtain, and the 1993 Privatization Act was followed by various IPOs ${ }^{42}$. Formerly state-owned companies were (partially) privatized and listed on the stock exchange (e.g., Voestalpine, OMV, Telekom, or Post). Today, the state still holds stakes in listed companies (e.g., OMV, Post,

40 Cf. Djankov, La Porta, Lopez-de-Silanes and Shleifer (2008)

41 Cf. Rose (2012)

42 Cf. Ruhm (2009) 
and Telekom) via Österreichische Industrieholding AG (ÖIAG). Furthermore, some companies are controlled by private foundations, which were founded either by families (Custos Privatstiftung, Haselsteiner Familien-Privatstiftung, MS Privatstiftung) or companies (e.g., B\&C Industrieholding). Private foundations have been a popular instrument since the reform of the foundation law in 1993. The purpose of the B\&C Industrieholding foundation is, for example, "to promote Austrian entrepreneurship. As a shareholder of Austrian industrial companies that are important for the Austrian economy, it offers them long-term stable ownership and thus secured development opportunities" (cf. foundation purpose of B\&C Industrieholding). The Austrian corporate governance code ("Österreichischer Corporate Governance Kodex") also contains specific recommendations. In some cases, a waiting period of two years when changing from the Management Board to the Supervisory Board is required.

France: In France, companies are traditionally managed by the Président-DirecteurGénéral (PDG). This means that the chairman of the supervisory board is also the chairman of the management board, although a different system would be possible today. France's supervisory boards are often selected from graduates of the Grandes Écoles, and reciprocal representation on supervisory boards is widespread ${ }^{43}$. A women's quota (40 percent of board members must be women) has been introduced in 2011. In addition, supervisory board members can be elected from among employees. A further peculiarity is the double voting right ("double droits de vote"): Shareholders who keep their shares for more than two years are rewarded a double number of voting rights, hereby creating an incentive for long-term orientation of the shareholders (e.g., Bouygues). This, however, results in a violation of the equality of voting rights and cash flow rights. In addition, the companies can limit the maximum voting rights, e.g., to 29.9 percent (as with Valneva). Due to the provisions of the French Commercial Code (Art. L225-122), according to which each share carries at least one vote, it is not possible to issue non-voting shares. In addition, the state often intervenes in company decisions, for example in mergers that could affect different stakeholders.

Germany: A defining element of German corporate governance is the two-tier board system. The management board is strictly separated from the supervisory board. The supervisory board controls the management, but has only little influence on daily business. In addition, there is employee co-determination at the highest company level: the supervisory boards of stock corporations with more than 2,000 employees are equally staffed by employees and shareholder representatives, one third of employee representation is required for companies with more than 500 employees, and the co-determination rule does not apply to companies with less than 500 employees $^{44}$. Since 1976, German boards are legally required to have at least 12 directors if the company has between 2001 and 10,000 domestic employees, 16 directors for companies with 10,001 to 20,000 domestic employees, and 20 directors for companies with more than 20,000 domestic employees ${ }^{45}$. The stakeholder concept is also strongly anchored ${ }^{46}$. Company decisions should take into account the interests of many stakeholders, especially employees with work councils. In the past, German companies also had a strong relationship with their house bank, which was

43 Cf. Nguyen (2012)

44 Cf. Hopt and Leyens (2004)

45 Cf. Jenter, Schmid, and Urban (2018)

46 Cf. Morck and Yeung (2009) 
often both a shareholder and a creditor at the same time ${ }^{47}$. In addition, many companies were connected by cross-shareholdings or controlled by families. These cross-shareholdings ensured some kind of self-coordination of the German economy. As a result of internationalization, however, this network has been reduced ${ }^{48}$.

Italy: The traditional (and still predominant) board system provides the delegation of operational tasks to a managing director or a committee. In addition, there is the "collegio sindicale", which consists only of independent board members and monitors compliance with regulations ${ }^{49}$. Both are on equal level (horizontal) and elected by the Annual General Meeting. However, formally independent supervisory boards are often close to the majority shareholder ${ }^{50}$. Since 2004, it has also been possible (like in France) to choose between a monistic (as in the U.S.) or a dualistic model with a supervisory board which is superior to the management board (like in Germany). Another typical feature of Italian corporate governance is family control through pyramid-like ownership structures comparable to Asian business groups. In this case, a company would be controlled by at least one other company, which in turn is controlled by a major shareholder. Such pyramids make it possible to achieve large voting shares with relatively small cash flow rights. This way, for instance, the Agnelli family controls companies with a total of over 400,000 employees ${ }^{51}$. Not least because of such opaque financial structures with a major shareholder at the top, who may also be CEO and chairman of the supervisory board, the Italian corporate governance system is seen as vulnerable for corporate scandals such as industrial espionage (2004: Marco Tronchetti Provera; Pirelli) or falsification of bank documents and balance sheets (2003: Tanzi family; Parmalat) ${ }^{52}$. Mussolini's party already controlled the Italian economy through a series of vertical control chains ${ }^{53}$. At that time, the system of corporatism spread to other dictator-led nations such as Austria, Spain and Portugal as far as South America, but also to Baltic states, the Balkan states and Arab countries ${ }^{54}$.

Switzerland: Measured by its size, Switzerland has a large number of big companies. The Swiss "Verwaltungsrat" is organized on a monistic basis. It leads the company and bears the ultimate responsibility. However, "transferable" operational tasks are usually delegated to a managing director, a board committee or an executive board. In the latter case, it would be a dualistic system ${ }^{55}$. One notable special feature concerns the restriction of voting rights through the so-called "transfer restrictions". Companies can refuse entry in the share register if a certain percentage of voting rights is exceeded (usually 3 percent) or if the beneficial owners cannot be identified. In rare cases, the registration of foreigners in connection with the Lex Koller may be refused. This way, companies immunize themselves against the influence of potentially hostile shareholders. On the other hand, the influence on companies can be consolidated by means of different share classes, for example by issuing non-voting shares or shares with different nominal values. Large companies such as Roche, Richemont or Swatch are family-controlled through such structures.

47 Cf. Franks and Mayer (2001)

48 Cf. Bessler, Drobetz and Holler (2013)

49 Cf. Melis (2004)

50 Cf. Di Pietra, Grambovas, Raonic and Riccaboni (2008)

51 Cf. Di Carlo (2014)

52 Cf. Enriques and Volpin (2007)

53 Cf. Morck and Yeung (2009)

54 Cf. Morck and Yeung (2009)

55 Cf. Bühler (2012) 


\section{Empirical Analysis}

\subsection{Data and descriptive statistics}

To examine the influence of the institutional framework on the structure of corporate governance, we gather information on corporate governance from five countries in Western Europe: Austria, France, Germany, Italy, and Switzerland. Specifically, we focus on the largest companies using the countries' components of their blue-chip indices: ATX, CAC40, DAX, FTSE MIB, and SMI. Due to data availability, and given that some legal changes occurred after 2014 (e.g., Loi Florange in France or Ordinance Against Excessive Remuneration at Listed Companies in Switzerland), we focus on year 2014. We obtain information on ownership structures from Thomson ONE Banker's database. We hand collect data on the boards of directors mainly from annual reports, companies' webpages, and SpencerStuart's "Board Index». Finally, we gathered financial data from Thomson Reuters Datastream. The descriptive statistics in Table 2 give an overview of corporate governance features in the countries of our analysis. The respective indices comprise 20 to 40 of the largest listed companies. In addition to the index properties, detailed key figures on the ownership structure, shareholder type, board of directors and financial information are displayed.

Table 2: Descriptive statistics

\begin{tabular}{|c|c|c|c|c|c|c|}
\hline Panel A: Index Properties & Austria & France & Germany & Italy & $\begin{array}{l}\text { Switzer- } \\
\text { land }\end{array}$ & Total \\
\hline Index & ATX & CAC40 & DAX & FTSE MIB & SMI & \\
\hline Index name & $\begin{array}{l}\text { Austrian } \\
\text { Traded } \\
\text { Index }\end{array}$ & $\begin{array}{l}\text { Cotation } \\
\text { Assistée } \\
\text { en } \\
\text { Continu }\end{array}$ & $\begin{array}{l}\text { Deutscher } \\
\text { Aktien- } \\
\text { index }\end{array}$ & $\begin{array}{l}\text { Financial } \\
\text { Times } \\
\text { Stock } \\
\text { Exchange } \\
\text { Milano } \\
\text { Italia } \\
\text { Borsa }\end{array}$ & $\begin{array}{l}\text { Swiss } \\
\text { Market } \\
\text { Index }\end{array}$ & \\
\hline Companies & 20 & 40 & 30 & 40 & 20 & 150 \\
\hline Two share classes & $0.0 \%$ & $0.0 \%$ & $16.7 \%$ & $17.5 \%$ & $15.0 \%$ & $10.0 \%$ \\
\hline Number of shareholders & 190 & 500 & 552 & 268 & 558 & 415 \\
\hline Cumulated voting rights & $64.2 \%$ & $50.0 \%$ & $48.6 \%$ & $57.8 \%$ & $49.2 \%$ & $53.6 \%$ \\
\hline Voting rights of largest shareholder & $38.1 \%$ & $18.7 \%$ & $17.8 \%$ & $34.7 \%$ & $16.9 \%$ & $25.1 \%$ \\
\hline $\begin{array}{l}\text { Largest shareholder of the same } \\
\text { country }\end{array}$ & $90.0 \%$ & $75.0 \%$ & $46.7 \%$ & $87.5 \%$ & $40.0 \%$ & $70.0 \%$ \\
\hline
\end{tabular}

Panel B: Shareholder type (>20 percent of voting rights)

- Family

- State

- Foundations

- Institutional investors

- Cooperatives

$\begin{array}{rrr}30.0 \% & 17.5 \% & 20.0 \% \\ 25.0 \% & 10.0 \% & 6.7 \% \\ 15.0 \% & 0.0 \% & 6.7 \% \\ 0.0 \% & 0.0 \% & 0.0 \% \\ 0.0 \% & 2.5 \% & 0.0 \%\end{array}$

$20.0 \%$

$26.0 \%$

$25.0 \%$

$2.5 \%$

$2.5 \%$

$2.5 \%$
$5.0 \%$

$14.7 \%$

$0.0 \%$

$4.0 \%$

$0.0 \%$

$0.7 \%$

$0.0 \%$

$1.3 \%$ 
- Employees

- Industrial companies

- Financial companies

Controlled companies

Widely-held companies

U.S. ownership

U.K. ownership

Panel C: Board characteristics

Board size

CEO duality

Executive directors (\%)

Independent directors (\%)

Women (\%)

Foreigners (\%)

$\begin{array}{rrrrrr}0.0 \% & 2.5 \% & 0.0 \% & 0.0 \% & 0.0 \% & 0.7 \% \\ 0.0 \% & 0.0 \% & 0.0 \% & 2.5 \% & 0.0 \% & 0.7 \% \\ 10.0 \% & 0.0 \% & 0.0 \% & 0.0 \% & 0.0 \% & 1.3 \% \\ 80.0 \% & 32.5 \% & 33.3 \% & 75.0 \% & 25.0 \% & 49.3 \% \\ 20.0 \% & 67.5 \% & 66.7 \% & 25.0 \% & 75.0 \% & 50.7 \% \\ 5.30 \% & 10.23 \% & 9.81 \% & 5.14 \% & 17.77 \% & 9.14 \% \\ 1.70 \% & 3.12 \% & 3.32 \% & 3.29 \% & 3.49 \% & 3.07 \%\end{array}$

$\begin{array}{rrrrrr}11.8 & 14.0 & 16.5 & 13.5 & 11.0 & 13.7 \\ 0.0 \% & 65.0 \% & 0.0 \% & 20.0 \% & 10.0 \% & 24.0 \% \\ 0.0 \% & 10.1 \% & 0.0 \% & 20.4 \% & 6.0 \% & 9.0 \% \\ 96.0 \% & 61.8 \% & 91.8 \% & 51.9 \% & 85.1 \% & 72.8 \% \\ 11.6 \% & 22.3 \% & 18.2 \% & 6.3 \% & 14.5 \% & 14.7 \% \\ 8.2 \% & 29.8 \% & 15.1 \% & 12.0 \% & 56.3 \% & 22.8 \%\end{array}$

Panel D: Company characteristics

\begin{tabular}{lrrrrrc} 
Total Assets & 24947 & 188000 & 174900 & 89552 & 163300 & 134100 \\
Debt & 21208 & 166500 & 154600 & 78711 & 143600 & 118300 \\
Equity & 3302 & 19981 & 19043 & 9383 & 18587 & 14558 \\
Sales & 5910 & 35640 & 45453 & 19722 & 25277 & 28012 \\
\hline
\end{tabular}

The variables are defined as follows: "Two share classes" is 1 if the company has two classes of shares outstanding. "Number of shareholders" is the number of shareholders and "Cumulated voting rights" measures the sum of share ownership of all shareholders. Data of both variables is from Thomson One Banker database. This figure mainly includes institutional investors. It shows that the companies from Germany, France and Switzerland not only have a higher number of shareholders (approx. 500 as listed in Thomson One Banker's database), the cumulated voting rights and voting rights of the largest shareholder are also lower, and the shareholder base is more international than in Italy and Austria. In the two latter countries, on the other hand, a concentrated shareholder structure is more common. This may be the case because Italian and Austrian companies are on average smaller. "Controlled companies" are defined as companies where the largest shareholder holds more than 20 percent of the voting rights ${ }^{56}$. In both cases, this is most often a family (or an individual) with 40 percent (Italy) and 30 percent (Austria). However, families also control many companies in Germany (20 percent), France (17.5 percent) and Switzerland (20 percent). In Italy and Austria, the state is the largest shareholder in one quarter of the companies. "Widely-held companies" are companies that are not controlled by a large shareholder that owns more than 20 percent of voting rights. "US" or "UK ownership" is the sum of voting rights held by investors from the United States of America or from the United Kingdom as indicated in Thomson One Banker. Data on

56 Cf. La Porta, Lopez-de-Silanes and Shleifer (1999); Faccio and Lang (2002) 
board characteristics has been hand-collected mainly from annual reports. Board size is the number of board members. CEO duality is 1, if the CEO and the Chairman are the same person. "Executive directors" denotes the fraction of the board whose members also hold executive positions in the company and "Independent directors" are directors defined as independent in the country's respective regulations (i.e., they are not executives and have no material business relationships with the company). "Women" and "Foreigners" are the fractions of the board of directors of female or foreign directors. Total Assets, Debt, Equity describe balance sheet items. Sales is the top line figure from the income statement. All information is gathered from Thomson Reuters Datastream.

In the empirical analysis, we examine whether and to what extent institutional differences (measured by country affiliation) and the differences in the operating environment (measured by company size and industry affiliation) influence corporate governance structures. According to the Industry Classification Benchmark (ICB), four main industry segments are distinguished: Industrials (ICB: 2000), consumer goods and services (ICB: 3000), financials (ICB: 8000) and health care (ICB: 4000). Some sectors are furthermore subject to different regulatory requirements. In Switzerland, for example, two-tier board systems are mandatory for banks. Possible differences are therefore not only due to a different operating environment.

\subsection{Ownership structure}

In a first step, we examine whether the prevalence of widely-held companies (as it can be observed in common law countries) on the one hand and companies controlled by families on the other differs across the five civil law countries. The literature review has shown that ownership structures in particular depend, to a considerable extent, on the respective legal environment and that this is decisive for shareholder democracy, i.e., the participation in the decision-making process within a company. Furthermore, we control for the industry characteristics. Since the variables "widely-held company" and "family" as dependent indicator variables assume values of 1 or 0 , we run logistic regressions.

The results are displayed in table 3 . Both the country environment and the industry environment are linked to the ownership structure of firms. Based on the reference country Austria, widely-held companies are more widespread in France, Germany and Switzerland. The country affiliation hereby has a significant explanatory power for ownership structure (McFadden: 16.4\%). This coincides with the findings from descriptive statistics. The results show that family businesses (among the largest companies surveyed) are less common only in Switzerland. The findings also show that firms in the financial sector tend to have a more dispersed ownership structure, while consumer goods and services rather exhibit a more concentrated ownership. However, company size does not play a significant role with respect to ownership structure. Overall, family-controlled companies are more common in the industrial, consumer goods and consumer service sectors, and the models, including the operating environment, correspondingly have higher explanatory power $(26.4 \%$ compared to $6.0 \%)$. 
Table 3: Ownership structure

\begin{tabular}{|c|c|c|c|c|}
\hline & \multicolumn{2}{|c|}{ Widely-held company } & \multicolumn{2}{|c|}{ Family } \\
\hline & (I) & (II) & (III) & (IV) \\
\hline (Intercept) & $\begin{array}{r}-1.38629 \quad(* *) \\
(0.588)\end{array}$ & $\begin{array}{r}0.56248 \\
(2.463)\end{array}$ & $\begin{array}{r}-1.09861 \quad(* *) \\
(0.544)\end{array}$ & $\begin{array}{r}-0.67915 \\
(3.559)\end{array}$ \\
\hline France & $\begin{array}{r}2.11718 \quad(* * *) \\
(0.683)\end{array}$ & $\begin{array}{r}3.42784 \quad(* * *) \\
(1.098)\end{array}$ & $\begin{array}{r}-0.63599 \\
(0.708)\end{array}$ & $\begin{array}{r}-1.35617 \\
(0.940)\end{array}$ \\
\hline Germany & $\begin{array}{r}2.07944 \quad \text { (***) } \\
(0.712)\end{array}$ & $\begin{array}{l}3.44999 \quad(* * *) \\
(1.153)\end{array}$ & $\begin{array}{r}-0.28768 \\
(0.720)\end{array}$ & $\begin{array}{r}-1.07675 \\
(0.976)\end{array}$ \\
\hline Italy & $\begin{array}{r}0.28768 \\
(0.698)\end{array}$ & $\begin{array}{r}0.53773 \\
(0.856)\end{array}$ & $\begin{array}{r}0.69315 \\
(0.636)\end{array}$ & $\begin{array}{r}0.62884 \\
(0.703)\end{array}$ \\
\hline Switzerland & $\begin{array}{r}2.77259 \quad(* * *) \\
(0.832)\end{array}$ & $\begin{array}{r}4.02983 \quad(* * *) \\
(1.186)\end{array}$ & $\begin{array}{r}-1.09861 \\
(0.954)\end{array}$ & $\begin{array}{r}-1.88840 \quad(*) \\
(1.014)\end{array}$ \\
\hline $\log$ Sales & & $\begin{array}{r}-0.18237 \\
(0.168)\end{array}$ & & $\begin{array}{r}-0.04192 \\
(0.228)\end{array}$ \\
\hline Industrials & & $\begin{array}{r}-0.52428 \\
(0.636)\end{array}$ & & $\begin{array}{r}1.23782 \quad(*) \\
(0.676)\end{array}$ \\
\hline $\begin{array}{l}\text { Consumer goods and ser- } \\
\text { vices }\end{array}$ & & $\begin{array}{r}-0.86937 \\
(0.605)\end{array}$ & & $\begin{array}{r}2.68642 \quad(* * *) \\
(0.691)\end{array}$ \\
\hline Financials & & $\begin{aligned} 1.97961 \quad(* * *) \\
(0.733)\end{aligned}$ & & $\begin{array}{r}-1.39542 \\
(0.868)\end{array}$ \\
\hline Health care & & $\begin{array}{r}-0.75665 \\
(0.915)\end{array}$ & & $\begin{array}{r}0.23440 \\
(1.746)\end{array}$ \\
\hline McFadden & $16.4 \%$ & $26.8 \%$ & $6.0 \%$ & $26.4 \%$ \\
\hline
\end{tabular}

Standard errors are reported in parentheses and significance at the 1 percent, 5 percent, and 10 percent levels is indicated by $* * *, * *, *$ respectively.

\subsection{Board size}

In the next step, we examine which factors influence the size and composition of the board of directors. The board of directors is responsible for a company's strategy, for selecting and supervising the management and it bears the ultimate responsibility. It has sometimes been argued that smaller boards of directors work more efficiently. Various studies have found a positive effect of smaller boards on firm performance ${ }^{57}$. However, the regulations following various corporate scandals resulted in the creation of specialized committees within the board of directors (e.g., audit, risk, nomination and compensation committees), hence contributing to larger boards instead. In addition to the institutional framework and the operational environment, ownership structure is seen to have a considerable influence on the size and the composition of the board of directors. We measure this relationship using OLS. 
Table 4: Board size

\begin{tabular}{|c|c|c|c|c|c|}
\hline \multicolumn{6}{|c|}{$\log$ Board size } \\
\hline & (I) & & (II) & (III) & \\
\hline (Intercept) & $\begin{array}{r}2.40180 \\
(0.088)\end{array}$ & $(* * *)$ & $\begin{array}{r}2.41470 \quad(* * *) \\
(0.096)\end{array}$ & $\begin{array}{r}0.84531 \\
(0.323)\end{array}$ & $(* * *)$ \\
\hline France & $\begin{array}{r}0.21489 \\
(0.095)\end{array}$ & $(* *)$ & $\begin{array}{r}0.20817 \quad(* *) \\
(0.100)\end{array}$ & $\begin{array}{r}0.02588 \\
(0.083)\end{array}$ & \\
\hline Germany & $\begin{array}{r}0.36729 \\
(0.103)\end{array}$ & $(* * *)$ & $\begin{array}{l}0.36056 \quad * * *) \\
(0.107)\end{array}$ & $\begin{array}{r}0.14054 \\
(0.094)\end{array}$ & \\
\hline Italy & $\begin{array}{r}0.15563 \\
(0.101)\end{array}$ & & $\begin{array}{r}0.15870 \\
(0.105)\end{array}$ & $\begin{array}{r}0.04088 \\
(0.092)\end{array}$ & \\
\hline Switzerland & $\begin{array}{r}-0.05428 \\
(0.116)\end{array}$ & & $\begin{array}{r}-0.06358 \\
(0.122)\end{array}$ & $\begin{array}{r}-0.22426 \\
(0.105)\end{array}$ & $(* *)$ \\
\hline Family & & & $\begin{array}{r}-0.02047 \\
(0.067)\end{array}$ & $\begin{array}{r}0.01694 \\
(0.064)\end{array}$ & \\
\hline State & & & $\begin{array}{r}-0.03115 \\
(0.086)\end{array}$ & $\begin{array}{r}0.00272 \\
(0.070)\end{array}$ & \\
\hline $\log$ Sales & & & & $\begin{array}{r}0.10129 \\
(0.019)\end{array}$ & $(* * *)$ \\
\hline Industrials & & & & $\begin{array}{r}0.00444 \\
(0.054)\end{array}$ & \\
\hline Consumer goods and services & & & & $\begin{array}{r}0.08139 \\
(0.077)\end{array}$ & \\
\hline Financials & & & & $\begin{array}{r}0.15487 \\
(0.066)\end{array}$ & $(* *)$ \\
\hline Health care & & & & $\begin{array}{r}0.00860 \\
(0.131)\end{array}$ & \\
\hline Multiple $\mathrm{R}^{2}$ & $18.0 \%$ & & $18.1 \%$ & $37.6 \%$ & \\
\hline Adjusted $\mathrm{R}^{2}$ & $15.7 \%$ & & $14.7 \%$ & $32.6 \%$ & \\
\hline$F$ & 7.9 & $(* * *)$ & $5.3(* * *)$ & 7.5 & $(* * *)$ \\
\hline
\end{tabular}

Standard errors are reported in parentheses and significance at the 1 percent, 5 percent, and 10 percent levels is indicated by $* * *, * *$, respectively.

The regression results give evidence that boards of directors are larger in France and Germany, although their structure (monistic vs. dualistic) is different (table 4). Interestingly, however, the institutional framework does not seem to play a significant role in this respect, if both the size of the company and the respective industries are controlled for. This result also shows that boards of directors in Switzerland are significantly smaller. In line with previous research, the number of board members is positively correlated with the size of the company. Larger companies tend to be more complex which may explain larger board sizes. Financials also have larger boards of directors. This may be due to the regulation and networking function of the financial industry, which may necessitate a larger number of members on their board of directors. The results show that the operating environment has a bigger influence on board size than the institutional framework or the ownership structure. Both family-control and state-control are not significantly related to board size. 


\subsection{Board independence}

As the third key element of corporate governance, we analyze the independence of the board of directors. Higher board independence is a frequent request of regulators and institutional investors. The criterion of "independence" refers to the relationship between a board member and the company. Current (executive board members, so-called "insiders") and former employees are typically qualified as non-independent. Non-executive board members who are nevertheless not independent are referred to as "affiliated" board members. In connection with independence, the CEO duality should also be considered (i.e.,

Table 5: Board independence

\begin{tabular}{|c|c|c|c|c|c|c|}
\hline & \multicolumn{2}{|c|}{ Executive directors (\%) } & \multicolumn{2}{|c|}{ CEO duality } & \multicolumn{2}{|c|}{ Independent directors (\%) } \\
\hline & (I) & (II) & (III) & (IV) & $(\mathrm{V})$ & (VI) \\
\hline (Intercept) & $\begin{array}{l}0.10145(* * *) \\
(0.016)\end{array}$ & $\begin{array}{l}0.36301 \quad(*) \\
(0.200)\end{array}$ & $\begin{array}{l}0.61904 \quad *) \\
(0.340)\end{array}$ & $\begin{array}{r}-4.41605 \\
(5.009)\end{array}$ & $\begin{array}{l}0.96028(* * *) \\
(0.022)\end{array}$ & $\begin{array}{l}0.89881(* * *) \\
(0.193)\end{array}$ \\
\hline France & & & & & $\begin{array}{c}-0.34282(* * *) \\
(0.038)\end{array}$ & $\begin{array}{l}-0.34982(* * *) \\
(0.057)\end{array}$ \\
\hline Germany & & & & & $\begin{array}{r}-0.04194 \\
(0.032)\end{array}$ & $\begin{array}{r}-0.03364 \\
(0.044)\end{array}$ \\
\hline Italy & $\begin{array}{l}0.10275(* * *) \\
(0.033)\end{array}$ & $\begin{array}{l}0.07664(* *) \\
(0.037)\end{array}$ & $\begin{array}{l}-2.00533(* * *) \\
(0.529)\end{array}$ & $\begin{array}{l}-2.01336(* *) \\
(0.882)\end{array}$ & $\begin{array}{c}-0.44110 \quad(* * *) \\
(0.044)\end{array}$ & $\begin{array}{l}-0.41841(* *) \\
(0.047)\end{array}$ \\
\hline $\begin{array}{l}\text { Switzer- } \\
\text { land }\end{array}$ & $\begin{array}{r}-0.04097 \\
(0.028)\end{array}$ & $\begin{array}{c}-0.04485 \quad(*) \\
(0.026)\end{array}$ & $\begin{array}{l}-2.81626(* * *) \\
(0.855)\end{array}$ & $\begin{array}{l}-2.68994(* * *) \\
(0.938)\end{array}$ & $\begin{array}{l}-0.10963 \quad(* * *) \\
(0.039)\end{array}$ & $\begin{array}{l}-0.10535 \quad(* *) \\
(0.048)\end{array}$ \\
\hline Family & & $\begin{array}{r}0.03473 \\
(0.036)\end{array}$ & & $\begin{array}{r}1.09001 \\
(0.949)\end{array}$ & & $\begin{array}{l}-0.11508(* *)) \\
(0.041)\end{array}$ \\
\hline State & & $\begin{array}{r}0.00763 \\
(0.060)\end{array}$ & & $\begin{array}{r}-0.80517 \\
(0.956)\end{array}$ & & $\begin{array}{r}0.03565 \\
(0.056)\end{array}$ \\
\hline $\log$ Sales & & $\begin{array}{r}-0.01761 \\
(0.011)\end{array}$ & & $\begin{array}{r}0.30389 \\
(0.300)\end{array}$ & & $\begin{array}{r}0.00579 \\
(0.013)\end{array}$ \\
\hline Industrials & & $\begin{array}{r}0.05685 \\
(0.056)\end{array}$ & & $\begin{array}{r}0.11663 \\
(0.757)\end{array}$ & & $\begin{array}{r}-0.00492 \\
(0.039)\end{array}$ \\
\hline $\begin{array}{l}\text { Consumer } \\
\text { goods and } \\
\text { services }\end{array}$ & & $\begin{array}{l}0.10511 \quad(* *) \\
(0.049)\end{array}$ & & $\begin{array}{r}-0.09287 \\
(0.883)\end{array}$ & & $\begin{array}{r}-0.04788 \\
(0.044)\end{array}$ \\
\hline Financials & & $\begin{array}{r}-0.00066 \\
(0.037)\end{array}$ & & $\begin{array}{r}-0.61791 \\
(0.949)\end{array}$ & & $\begin{array}{r}-0.01069 \\
(0.043)\end{array}$ \\
\hline $\begin{array}{l}\text { Health } \\
\text { care }\end{array}$ & & $\begin{array}{r}-0.00576 \\
(0.034)\end{array}$ & & $\begin{array}{r}-1.09571 \\
(2.004)\end{array}$ & & $\begin{array}{l}-0.11732(* *) \\
(0.057)\end{array}$ \\
\hline $\begin{array}{l}\text { Multiple } \\
\mathrm{R}^{2 /} \mathrm{Mc}- \\
\text { Fadden }\end{array}$ & $15.9 \%$ & $29.0 \%$ & $19.8 \%$ & $26.2 \%$ & $50.0 \%$ & $56.8 \%$ \\
\hline $\begin{array}{l}\text { Adjusted } \\
\mathrm{R}^{2}\end{array}$ & $14.2 \%$ & $21.9 \%$ & & & $48.6 \%$ & $53.3 \%$ \\
\hline$F$ & $9.2(* * *)$ & $4.1(* * *)$ & & & $36.2(* * *)$ & $16.5(* * *)$ \\
\hline
\end{tabular}

Standard errors are reported in parentheses and significance at the 1 percent, 5 percent, and 10 percent levels is indicated by $* * *, * *$, respectively. 
whether the CEO is also the Chairman of the board). One problem with the first two criteria (proportion of executive board members and CEO duality) is that in Austria and Germany, there are no executive members on the Supervisory Board. These countries, as well as France (as a reference), hence cannot be considered in this part of the study. In table 5, columns I to IV compare Italy and Switzerland with France. Again, the models are estimated using OLS and logistic regressions (CEO duality: Yes=1, No=0).

As can be seen from table 5, there are more executive directors in Italy, although they act less frequently as chairmen of supervisory boards. The result can undoubtedly be explained by the PDG model in France and thus stresses the importance of the institutional framework. As far as independence is concerned, this seems to be most pronounced in Austria. Board independence is also lower in family-controlled companies and companies in the health care sector. It is also noteworthy that the institutional framework obviously has a decisive influence on the degree of board independence. After all, the model with country effects only explains about half of the variation in board independence, while the other variables in model VI only explain an additional 6.8 percent.

\subsection{Institutional and operating environment}

Overall, the results show that both the institutional environment and the operating environment do have an impact on corporate governance. However, the importance of the two determinants differs depending on the feature that is investigated. The institutional environment explains board independence and the proportion of widely-held companies, while the operating environment appears to have a higher explanatory power for the prevalence of family-controlled companies and board size. Neither of the hypotheses can therefore be rejected. It therefore seems that the country affiliation does have an impact on the typical setting of corporate governance, irrespective of the industry affiliation of the firm (Hypothesis 1). Within this setting, operating characteristics of firms active in specific industries have an impact on design of corporate governance mechanisms (Hypothesis 2).

\section{Conclusions}

The notion of corporate governance includes mechanisms ensuring that (all) shareholders are protected against value-decreasing activities by self-interested managers or major shareholders. In many countries outside the Anglo-Saxon world, shareholders are not only exposed to the principal-agent problem but are often affected by large shareholders' influence on corporate decisions.

Although the European Union has made various efforts since 2003 to harmonize corporate governance across Europe, there are still considerable differences between the institutional framework on the one hand and the operational environment and ownership structures on the other hand. We examine which factors influence corporate governance across five Western European countries based on ownership structure and board structure.

The results confirm that both the institutional framework and the operating environment have a considerable influence on how corporate governance is designed in firms within a specific country level in general but likewise among different sectors. The models explain up to $56.8 \%$ or at least $6 \%$ of the variation in the dependent variables. Despite the convergence trends and the fact that all considered countries belong to the same legal system (Civil Law), we find that country affiliation is important to explain both the distri- 
bution of ownership and the independence of the board of directors. In contrast, the operating environment does explain the size of the board and also the fact that ownership is rather spread in the financial services industry while being more concentrated in the consumer goods industry.

As a limitation, our study focuses on blue-chip companies solely. Hence, the reality of corporate governance in the respective countries is only reflected to a limited extent. Firstly, small and medium-sized enterprises often have different corporate governance systems. And secondly, large companies typically exhibit a high free float which exposes the firms to the influence of institutional investors and their demand for adhering to international standards. Furthermore, we focus on five countries in Continental Europe that explicitly follow the same legal tradition. Although this approach increases comparability and enables us to point out specific differences "below the surface", the results may therefore not be generally valid, as a matter of course.

Despite a certain convergence of corporate governance standards even in Continental Europe, different corporate governance structures can be observed due to country- and company-specific characteristics. Designing an efficient and contributive corporate governance depends on the firm's institutional framework, its operating environment, and its ownership structure. A further and binding harmonization may therefore have a negative impact on the effectiveness of corporate governance since it may not be suitable for all companies.

\section{Literature}

Adams, R. B., Hermalin, B. E., \& Weisbach, M. S. (2010). The Role of Boards of Directors in Corporate Governance: A Conceptual Framework and Survey. Journal of Economic Literature, 48(1), 58-107.

Admati, A. R./Pfleiderer, P. (2009): The "Wall Street Walk" and Shareholder Activism: Exit as a Form of Voice, in: Review of Financial Studies, 22(7), 2445-2485.

Aguilera, R. V./Jackson, G. (2003): The Cross-National Diversity of Corporate Governance: Dimensions and Determinants, in: Academy of Management Review, Vol. 28, No. 3, 447-465.

Allen, W. T./Kraakman, R./Subramanian, G. (2009): Commentaries and Cases on the Law of Business Organization, 3rd ed., New York.

Bebchuk, L. A./Roe, M. J. (1999): A Theory of Path Dependence in Corporate Ownership and Governance, in: Stanford Law Review, Vol. 52, No. 1, 127-170.

Beck, T./Demirgüç-Kunt, A./Levine, R. (2003): Law and Finance: Why Does Legal Origin Matter?, in: Journal of Comparative Economics, Vol. 31, No. 4, 653-675.

Beck, T./Levine, R. (2005): Legal Institutions and Financial Development, in: Menard, C./Shirley, M. (ed.): Handbook of New Institutional Economics, Springer.

Berkowitz, D./Pistor, K./Richard, J. F. (2003): Economic Development, Legality, and the Transplant Effect, in: European Economic Review, Vol. 47, No. 1, 165-195.

Berle, A./Means, G. (1932): The Modern Corporation and Private Property, New York.

Bessler, W./Drobetz, W./Holler, J. (2013): The Returns to Hedge Fund Activism in Germany. European Financial Management. doi: 10.1111/eufm.12004

Boone, A. L./Field, L. C./Karpoff, J. M./Raheja, C. G. (2007): The Determinants of Corporate Board Size and Composition: An Empirical Analysis. Journal of Financial Economics, Vol. 85, No. 1, 66-101. 
Bühler, C. B. (2012): Corporate Governance und ihre Regulierung in der Schweiz. Empfehlungen des "Swiss Code of Best Practice for Corporate Governance“ zur Nutzung der Gestaltungsfreiheit des Aktienrechts, Zeitschrift für Unternehmens- und Gesellschaftsrecht ZGR, 41, 228-245.

Claessens, S./Djankov, S./Lang, L. H. (2000): The Separation of Ownership and Control in East Asian Corporations, in: Journal of Financial Economics, Vol. 58, No. 1, 81-112.

Coffee, J. C. (1999). The future as history: The prospects for global convergence in corporate governance and its implications. Northwestern University Law Review, Vol. 93, No. 3, 641-707.

Coffee, J. C. (2001): The Rise of Dispersed Ownership: The Roles of Law and the State in the Separation of Ownership and Control, in: The Yale Law Journal, Vol. 111, No. 1, 1-82.

Coles, J. L./Daniel, N. D./Naveen, L. (2008): Boards: Does One Size Fit All?. Journal of Financial Economics, Vol. 87, No. 2, 329-356.

Conac, P. H./Enriques, L./Gelter, M. (2007): Constraining Dominant Shareholders' Self-dealing: The Legal Framework in France, Germany, and Italy, in: European Company and Financial Law Review, Vol. 4, No. 4, 491-528.

Denis, D. K./McConnell, J. J. (2003): International corporate governance. Journal of Financial and Quantitative Analysis, Vol 38, No. 1, 1-36.

DeYoung, R./Peng, E. Y./Yan, M. (2013): Executive Compensation and Business Policy Choices at US Commercial Banks, Journal of Financial and Quantitative Analysis, Vol. 48, No. 1, 165-196.

Doh, J. P./Guay, T. R. (2006): Corporate Social Responsibility, Public Policy, and NGO Activism in Europe and the United States: An Institutional-Stakeholder Perspective. Journal of Management Studies, Vol. 43, No. 1, 47-73.

Di Carlo, E. (2013): Pyramids and the Separation between Direction and Control of Non-financial Italian Family Companies, in: Journal of Management \& Governance, Vol. 18, No. 3, 835-872.

Di Pietra, R./Grambovas, C. A./Raonic, I./Riccaboni, A. (2008): The Effects of Board Size and 'Busy'Directors on the Market Value of Italian Companies, in: Journal of Management \& Governance, Vol. 12, No. 1, 73-91.

Doidge, C., Karolyi, A., Stulz, R. (2007): Why do Countries Matter so Much for Corporate Governance?, in: Journal of Financial Economics, Vol. 86, 1-39.

Djankov, S./La Porta, R./Lopez-de-Silanes, F./Shleifer, A. (2008): The Law and Economics of Selfdealing, in: Journal of Financial Economics, Vol. 88, No. 3, 430-465.

Djankov, S./La Porta, R./Lopez-de-Silanes, F./Shleifer, A. (2008). The Law and Economics of Selfdealing. Journal of Financial Economics, 88(3), 430-465.

Dyck, A./Zingales, L. (2004): Private Benefits of Control: An International Comparison, in: The Journal of Finance, Vol. 59, No. 2, 537-600.

Enriques, L./Volpin, P. (2007): Corporate Governance Reforms in Continental Europe, in: The Journal of Economic Perspectives, Vol. 21, No. 1, 117-140.

Faccio, M./Lang, L. H. (2002): The Ultimate Ownership of Western European Corporations, in: Journal of Financial Economics, Vol. 65, No. 3, 365-395.

Fama, E. F./Jensen, M. C. (1983): Agency Problems and Residual Claims, in: Journal of Law and Economics, Vol. 26, No. 2, 327-49.

Ferris, S. P./Kim, K. A./Kitsabunnarat, P. (2003): The Costs (and Benefits?) of Diversified Business Groups: The Case of Korean Chaebols, in: Journal of Banking \& Finance, Vol. 27, No. 2, 251273.

Franks, J./Mayer, C. (2001). Ownership and Control of German Corporations, in: Review of Financial Studies, Vol. 14, No. 4, 943-977. 
Franks, J./Mayer, C./Rossi, S. (2009): Ownership: Evolution and Regulation, in: Review of Financial Studies, Vol. 22, No. 10, 4009-4056.

Freeman, R.E. (1984): Strategic Management - A Stakeholder Approach. Boston: Pitman.

Friedman, M. (1970): The Social Responsibility of Business is to Increase its Profits, in: The New York Times Magazine, September 13.

Gelderblom, O./De Jong, A./Jonker, J. (2013): The Formative Years of the Modern Corporation: The Dutch East India Company VOC, 1602-1623, in: The Journal of Economic History, Vol. 73, No. 4, 1050-1076.

Gillan, S. (2006): Recent Developments in Corporate Governance: An Overview, in: Journal of Corporate Finance, Vol. 12, No. 3, 381-402.

Gillan, S. L./Starks, L. T. (2007): The Evolution of Shareholder Activism in the United States, in: Journal of Applied Corporate Finance, Vol. 19, No. 1, 55-73.

Griffin, D., Guedhami, O., Kwok, C. C., Li, K., \& Shao, L. (2017). National Culture: The Missing Country-Level Determinant of Corporate Governance. Journal of International Business Studies, 48(6), 740-762.

Hall, P. A./Soskice, D. (2001): Varieties of capitalism: The Institutional Foundations of Comparative Advantage, Oxford.

Hattori, T. (1989): Japanese Zaibatsu and Korean Chaebol, in: Chung, K.-H./Lee, H.-C. (ed.): Korean Managerial Dynamics, New York.

Hermalin, B. E./Weisbach, M. S. (2003). Boards of Directors as an Endogenously Determined Institution: A Survey of the Economic Literature, in: Economic Policy Review, Vol. 9, No. 1, 7-26.

Hopt, K. J./Leyens, P. C. (2004): Board Models in Europe-Recent Developments of Internal Corporate Governance Structures in Germany, the United Kingdom, France, and Italy, in: European Company and Financial Law Review, Vol. 1, No. 2, 135-168.

Jensen, M. C./Meckling, W. H. (1976): Theory of the Firm: Managerial Behavior, Agency Costs and Ownership Structure, in: Journal of Financial Economics, Vol. 3, No. 4, 305-360.

Jensen, M. C./Ruback, R. S. (1983). The Market for Corporate Control: The Scientific Evidence. Journal of Financial Economics, Vol. 11, No. 1, 5-50.

Jenter, D./Schmid, T./Urban, D. (2018). Does board dize matter? Working Paper

Johnson, S./Boone, P./Breach, A./Friedman, E. (2000). Corporate Governance in the Asian Financial Crisis. Journal of Financial Economics, Vol. 58, No. 1, 141-186.

Kaplan, S. N./Strömberg, P. (2003): Financial Contracting Theory Meets the Real World: An Empirical Analysis of Venture Capital Contracts. The Review of Economic Studies, Vol. 70, No. 2, 281-315.

Klapper, L. F./Love, I. (2004): Corporate Governance, Investor Protection, and Performance in Emerging Markets. Journal of Corporate Finance, Vol. 10, No. 5, 703-728.

Klapper, L.F., Laeven, L., Love, I. (2006): What Drives Corporate Governance? Firm-level Evidence from Eastern Europe. World Bank Policy Research Working Paper Series, No. 3600.

La Porta, R./Lopez-de-Silanes, F./Shleifer, A./Vishny, R. W. (1998): Law and Finance, in: Journal of Political Economy, Vol. 106, No. 6, 1113-1155.

La Porta, R./Lopez-de-Silanes, F./Shleifer, A./Vishny, R. W. (2000): Investor Protection and Corporate Governance, in: Journal of Financial Economics, Vol. 58, No. 1, 3-27.

La Porta, R./Lopez-de-Silanes, F./Shleifer, A. (1999): Corporate Ownership Around the World, in: Journal of Finance, Vol. 54, No. 2, 471-517. 
La Porta, R./Lopez-de-Silanes, F./Shleifer, A. (2008): The Economic Consequences of Legal Origins, in: Journal of Economic Literature, Vol. 46, No. 2, 285-332.

Lehn, K. M./Patro, S./Zhao, M. (2009): Determinants of the Size and Composition of US Corporate Boards: 1935- 2000. Financial Management, Vol. 38, No. 4, 747-780.

Linck, J. S./Netter, J. M./Yang, T. (2008): The Determinants of Board Structure. Journal of Financial Economics, Vol. 87, No. 2, 308-328.

Lipton, M./Lorsch, J. W. (1992). A Modest Proposal for Improved Corporate Governance, in: The Business Lawyer, Vol. 48, No. 1, 59-77.

Nguyen, B. D. (2012): Does the Rolodex matter? Corporate Elite's Small World and the Effectiveness of Boards of Directors, in: Management Science, Vol. 58, No. 2, 236-252.

North, D. C. (1990): Institutions, Institutional Change and Economic Performance. Cambridge Univ. Press, Cambridge.

Mehran, H. (1995): Executive Compensation Structure, Ownership, and Firm Performance, in: Journal of Financial Economics, Vol. 38, No. 2, 163-184.

Melis, A. (2004): On the Role of the Board of Statutory Auditors in Italian Listed Companies. Corporate Governance: An International Review, Vol. 12, No. 1, 74-84.

Morck, R./Yeung, B. (2005): Dividend Taxation and Corporate Governance, in: Journal of Economic Perspectives, Vol. 19, No. 3, 163-180.

Morck, R./Yeung, B. (2009): Never Waste a Good Crisis: An Historical Perspective on Comparative Corporate Governance. Annual Review of Financial Economics, Vol. 1, 145-179.

Pagano, M./Volpin, P. (2001): The Political Economy of Finance. Oxford Review of Economic Policy, Vol. 17, No. 4, 502-519.

Pargendler, M. (2019): The Grip of Nationalism on Corporate Law. European Corporate Governance Institute (ECGI), Law Working Paper No. 437.

Rappaport, A. (1986): Creating Shareholder Value - The New Standard for Business Performance. New York: Simon und Schuster Ltd.

Roe, M. J. (1991): A Political Theory of American Corporate Finance, in: Columbia Law Review, Vol. 91, No. 1, 10-67.

Rose, C. (2012). The New European Shareholder Rights Directive: Removing Barriers and Creating Opportunities for More Shareholder Activism and Democracy, in: Journal of Management \& Governance, Vol. 16, No. 2, 269-284.

Ruhm, F. (2009): Who Austria's Industry Belongs To, in: Gewinn extra, No. 6e, pp. 88-93.

Shleifer, A./Vishny, R. W. (1997). A Survey of Corporate Governance, in: The Journal of Finance, Vol. 52, No. 2, 737-783.

Shin, H./Park, Y. S. (1999): Financing Constraints and Internal Capital Markets: Evidence from Korean Chaebols, in: Journal of Corporate Finance, Vol. 5, No. 2, 169-191.

Smith, A. (1776): An Inquiry into the Nature and Causes of the Wealth of Nations, London.

Villalonga, B./Amit, R. (2006): How Do Family Ownership, Control and Management Affect Firm Value?. Journal of Financial Economics, Vol. 80, No. 2, 385-417.

World Bank Group (2014): World Development Indicators 2014. World Bank Publications.

Yermack, D. (1996). Higher Market Valuation of Companies with a Small Board of Directors, in: Journal of Financial Economics, Vol. 40, No. 2, 185-211. 
Pascal Gantenbein, Prof. Dr., ist Professor für Finanzmanagement an der Wirtschaftswissenschaftlichen Fakultät der Universität Basel.

Anschrift: Universität Basel, Wirtschaftswissenschaftliche Fakultät, Peter Merian-Weg 6, CH-4002 Basel, E-Mail: pascal.gantenbein@unibas.ch

Christophe Volonté, Dr., ist Lehrbeauftragter für Corporate Finance an der Wirtschaftswissenschaftlichen Fakultät der Universität Basel.

Anschrift: Universität Basel, Wirtschaftswissenschaftliche Fakultät, Peter Merian-Weg 6, CH-4002 Basel, E-Mail: christophe.volonte@unibas.ch 